\title{
Controle social no Sistema Único de Saúde: análise da participação social e empoderamento da população usuária do sistema sanitário
}

\author{
Poliana Cardoso Martins \\ policmartins@yahoo.com.br \\ Dissertação de Mestrado \\ Departamento de Nutrição e Saúde / Universidade Federal de Viçosa \\ Viçosa (MG), 2007
}

Os conselhos de saúde se tornaram um mecanismo estratégico para garantia da democratização do poder decisório no Sistema Único de Saúde (SUS). Esses espaços devem exercer importante papel para a efetiva participação da sociedade civil na tomada de decisão em saúde, e é essencial uma reflexão profunda sobre os matizes dessa utopia. É preciso avaliar os desafios encontrados e as possibilidades apresentadas para uma real participação social no país, ressaltar a necessidade de presença ativa dos sujeitos na construção do processo democrático no SUS e abrir a discussão sobre a necessidade de empoderamento/ libertação da população usuária do sistema. Nessa conjuntura, o Programa Saúde da Família (PSF) pode ser visto como importante estratégia na busca da participação mais ativa dos usuários na tomada de decisão. Diante desses pressupostos teóricos, a dissertação analisa a experiência do controle social pela via do Conselho Municipal de Saúde (CMS), buscando compreender a representação social dos usuários do PSF sobre a realidade do SUS, no município de Teixeiras (MG). O estudo situa-se no campo da pesquisa social e utiliza primordialmente o referencial teórico-metodológico-instrumental da pesquisa qualitativa, tendo sido entrevistados 32 conselheiros (84,2\% do total) e 136 usuários das unidades de saúde da família (USF) (11\% dos cadastrados no Hiperdia e que realizavam acompanhamento nas quatro USF). Estes últimos foram selecionados de forma aleatória durante os atendimentos e as atividades realizadas na USFs. Ao analisar a experiência do controle social em saúde, observa-se que a possibilidade de uma gestão participativa no SUS não se consolidou como prática efetiva de gestão pública. O que se verificou foi desconhecimento sobre as bases legais e ideológicas da participação social em saúde, abrindo espaço para forte influência dos gestores locais na dinâmica e no funcionamento do CMS, sobretudo na determinação de seus membros. Dessa forma impede-se que o CMS se torne um espaço concreto para que os usuários se apropriem institucional e politicamente do conselho, além de impedi-los de interferir, discutir e deliberar sobre as questões de saúde do município. As representações sociais dos usuários sobre o SUS demonstram uma visão marcada pela focalização da assistência, apontando para a concentração de recursos públicos em segmentos mais pobres da sociedade e, também, uma visão centrada no modelo de atenção biomédico. Ressalta-se também que o PSF não conseguiu alcançar seu objetivo de proporcionar mudanças na práxis em saúde, visando, além da assistência em saúde, estimular o empoderamento/libertação coletivo da população atendida. Os dados apresentados em ambas as avaliações apontam para um grande desconhecimento da população sobre o sistema sanitário, bem como sobre seus direitos sociais conquistados com a Constituição de 1988. Diante da realidade vivenciada, ressalta-se a necessidade de maior empoderamento/libertação da população, visando construir possibilidades efetivas para que esta seja participante ativa do processo de construção de um projeto assistencial comum, realmente fundamentado nos ideais democráticos do SUS, sendo o PSF estrategicamente importante na transformação dessa realidade. Um dos caminhos para tal mudança seria a realização de práticas educativas, de modo a transformar esses atores sociais em protagonistas da construção da sua própria história. 